\title{
Observations and Simulations of Basin Effects in the Kathmandu Valley During the 2015 Gorkha, Nepal, Earthquake Sequence
}

\author{
Domniki Asimaki, ${ }^{\text {a) }}$ M.EeRI, Kami Mohammadi, ${ }^{\text {a) }}$ Henry B. Mason, ${ }^{\text {b) }}$ M.EeRI, \\ Rachel K. Adams, ${ }^{\text {b) }}$ Sudhir Rajaure, ${ }^{\text {c) }}$ and Diwakar Khadka ${ }^{\text {d) }}$
}

The M7.8 Gorkha, Nepal main shock ruptured a segment of the Main Himalayan Thrust (MHT) directly below Kathmandu Valley, causing strong shaking levels across the valley. Strong-motion data reveal an initial $6 \mathrm{~s}$ source pulse that was amplified and reverberated within the basin. One of the striking features of the observed ground motions in the valley was the exceptionally low energy of periods less than $2 \mathrm{~s}$, which likely limited the extent and severity of structural damage in Kathmandu compared with alternative rupture scenarios of the same magnitude in the region. Isolated cases of liquefaction and lateral spreading of unconsolidated sediments were also observed, but have not yet revealed a systematic damage pattern. Initial analysis of available data suggests that several different factors, including source and path as well as site effects, were responsible for the unusual ground motions characteristics. In this paper, we provide a short description of the Kathmandu Valley geology and analyze available strong-motion records from the main shock and three strong aftershocks, with the intent to shed light on earthquake reconnaissance observations from this earthquake. [DOI: 10.1193/013117EQS022M]

\section{INTRODUCTION}

The 2015 Gorkha earthquake ruptured the segment of the Main Himalayan Thrust (MHT) directly beneath the Kathmandu Valley. The large magnitude and proximity to the valley caused strong shaking in Kathmandu, and caused localized - yet significant—structural damage and thousands of landslides (Collins and Jibson 2015). The few instrumental records of ground shaking that are now available indicate that the ground motions were relatively depleted in high frequency energy compared with what would be expected on average for earthquakes of similar size and distance (Moss et al. 2015). Hayes et al. (2015) summarized the rapid characterization of the event by the United States Geological Survey (USGS): despite the lack of available instrumental recordings at the time, and the peculiar nature of the ground motion frequency content, the USGS estimated that this event would result in around 9,000 fatalities and an intensity of up to IX on the modified Mercalli Intensity (MM) scale within four hours after the main shock. This fatality estimate was proven consistent with the best currently

\footnotetext{
a) California Institute of Technology, Department of Mechanical and Civil Engineering, Pasadena CA 91125

b) Oregon State University, Department of Civil and Construction Engineering, Corvallis OR 97331

c) Department of Mines and Geology, Government of Nepal, Lainchaur, Kathmandu, Nepal

d) ANDO HAZMA Co. Ltd, Japan
} 
available estimates, while a subsequent detailed study of structural damage caused by the main shock (McGowan et al. 2016) concluded that European Macroseismic Scale (EMS) intensities peaked in the VII-VIII range, which was slightly lower than originally estimated. In this paper, we analyse five strong-motion records of the main shock and aftershocks of the Gorkha sequence, four of which were made publically available approximately one year after the event. These records show that the Gorkha earthquake was characterized by a long-period $(5 \mathrm{~s})$ predominant pulse that reverberated in the valley for 4-5 cycles before gradually decaying; and on the same time, by a surprisingly low peak ground acceleration (PGA) of $0.16 \mathrm{~g}$ recorded at the station on rock outcrop. High-rate $(5 \mathrm{~Hz})$ GPS measurements recorded within the basin and on the surrounding mountain ranges (source: UNAVCO) were consistent with the strongmotion records, revealing significant amplification at periods longer than $2 \mathrm{~s}$.

The Kathmandu Valley has experienced numerous large earthquakes in the last 1,500 years (Pandey and Molnar 1988, Szeliga et al. 2010). The most recent large event was the M8.1-M8.4 Great Nepal-Bihar earthquake of 1934 (Bilham et al. 2001, Bollinger et al. 2014, Chen and Molnar 1977, Chitrakar and Pandey 1986, Sapkota et al. 2013). This event caused about 8,500 casualties and destroyed $20 \%$ and damaged $40 \%$ of the valley's building stock, including one quarter of the buildings in Kathmandu and many of the temples in Bhaktapur (Pandey and Molnar 1988). Within the basin, estimated intensities correlated qualitatively to the depth of the basin sediments, suggesting that site effects played a major role in modifying the 1934 event's ground motion within Kathmandu (Dixit et al. 1998). A number of studies have concluded that damage from the 1934 earthquake was accentuated by ground motion amplification in the fluvio-lacustrine sediments of the southern Kathmandu Valley and by liquefaction (Chitrakar and Pandey 1986, Pandey and Molnar 1988, Rana 1935, Paudyal et al, 2012a and 2012b, Rajaure et al. 2016).

While the importance of site response in the valley has long been clear, strong-motion data have been scarce and sparse, and the detailed nature of site effects has thus remained poorly understood. To date, site response studies in the Kathmandu Valley have relied almost exclusively on microtremor data (e.g., Pandey 2000, Paudyal et al. 2012a, 2012b). The strong-motion recordings from the 2015 Gorkha earthquake sequence in this paper provide a unique opportunity to better understand site effects on multiple spatial and frequency scales. In the following sections, we specifically analyze ground motions from the 25 April 2015 Gorkha main shock (M7.8), and compare them to the 12 May 2015 Dolakha aftershock (M7.3) and other moderateto-large aftershocks recorded at five strong-motion stations (four of which are located on unconsolidated sediments; one is located on reference rock) and two high-rate GPS records. Our analysis reveals that basin effects can explain the unusual long-period amplification that manifested in all four events presented later, albeit with small differences in absolute amplitude and fundamental frequency likely linked to nonlinear response of the shallow basin sediments. On the other hand, we show that the significant high frequency attenuation, which characterized the main shock records, is likely attributed to a combination of source and site effects.

\section{GEOLOGY OF THE KATHMANDU BASIN SEDIMENTS}

The Kathmandu basin lies on the Kathmandu Nappe (Hagen 1952) along the southern slopes of the Himalaya. A lake occupied a large part of the basin from Pliocene to Pleistocene (Yoshida and Igarashi 1984). The basin is currently filled with a very thick (500-600 m) 
sequence of fluvio-lacustrine sediments (Moribayashi and Maruo 1980) and is bound to the south by a tectonic ridge developed above the Main Boundary Thrust (MBT). On the northern part of the valley, sediments are poorly sorted, thin- to medium-bedded, highly micaceous coarse sand, gravel, and silts interlayered with clays. In the south, they consist of a thick sequence of dark gray to black highly plastic clay and silts, usually overlain and underlain by coarse sediments. The black plastic clay (locally called Kalimati or black cotton) is rich in organic matter. The age of this clay is placed in the Pliocene to Pleistocene time, according to Yoshida and Igarashi (1984). According to the same study, the maximum thickness of the black clay is approximately $300 \mathrm{~m}$, and is greatest along the central part of the valley starting from Satungal toward Lalitpur and Bhaktapur (Figure 2).

The sedimentation processes in the Kathmandu Valley are controlled by the regional fault activity and the drainage system of the surrounding mountains. According to Sakai et al. (2001), the active faults related to the basin sediment formation are on the southern part of the valley, the Chandragiri Fault and the Chobhar Fault, which run through the colluvial slopes and terraces of the Late Pleistocene, and on the northwest part of the valley, the Kalphu Khola Fault, which runs through the Late Pleistocene gneissic boulder beds (Nakata et al. 1998). The complex tectonic environment surrounding the Kathmandu basin is shown in Figure 2. As a consequence of this environment, the geology of the valley is strongly heterogeneous: the southern sediments are predominantly composed of weathered metasedimentary rocks from the southern hills, such as Chandragiri and Phulchowki, and the northern sediments are composed of weathered gneiss and granite from the northern Shivapuri hills.

Detailed geotechnical information of the velocity structure and material properties of the black clay in the Kathmandu Valley is not available. To our knowledge, Paudyal et al. (2012a) is the only recently published study that estimated the three-dimensional (3-D) geometry of the basement structure using seismic velocity measurements. In their study, Paudyal et al. (2012a) used PS suspension logging shear wave velocity profiles measured by the Japan International Cooperation Agency (JICA 2002) to estimate an average $V_{S 30}$ of $246.87 \mathrm{~m} / \mathrm{s}$ for the Kathmandu shallow layers (JICA 2002). Using this $V_{S 30}$ and the frequency of the second peak from their microtremor $\mathrm{H} / \mathrm{V}$ measurements (which ranged from $4-6 \mathrm{~Hz}$ across all stations), they back-calculated the thickness of the uppermost layer of the Kathmandu Valley between 10 and $15 \mathrm{~m}$.

In a follow-up study, Paudyal et al. (2012b) used the first mode (peak) of the microtremor measurements to estimate the depth of the valley basement. We should note here that their calculated depth of sediments represents the depth of lake deposits down to a strong impedance contrast, not necessarily to hard rock. Their study showed that the central part of the city of Kathmandu lies over the main ancient lake of the Kathmandu basin. Their study also revealed a number of shallower depressions across the basin and numerous buried ridges that separate/connect the depressions; the subsurface topographic map developed by Paudyal et al. (2012b) is shown in Figure 1. While Paudyal et al. (2012b) estimated a maximum basin depth of $250 \mathrm{~m}$, other studies have estimated maximum depths up to $500 \mathrm{~m}$ (e.g., Moribayashi and Maruo 1980, Sakai 2001, Figure 2). The strong geometric heterogeneity of the Kathmandu basement rock estimated by Paudyal et al. (2012b) (Figure 1) compares qualitatively well with the geological database compiled by Piya (2004) based on 250 drill holes deeper than $100 \mathrm{~m}$ and more than 100 shallow boreholes between $45 \mathrm{~m}$ and $100 \mathrm{~m}$. 


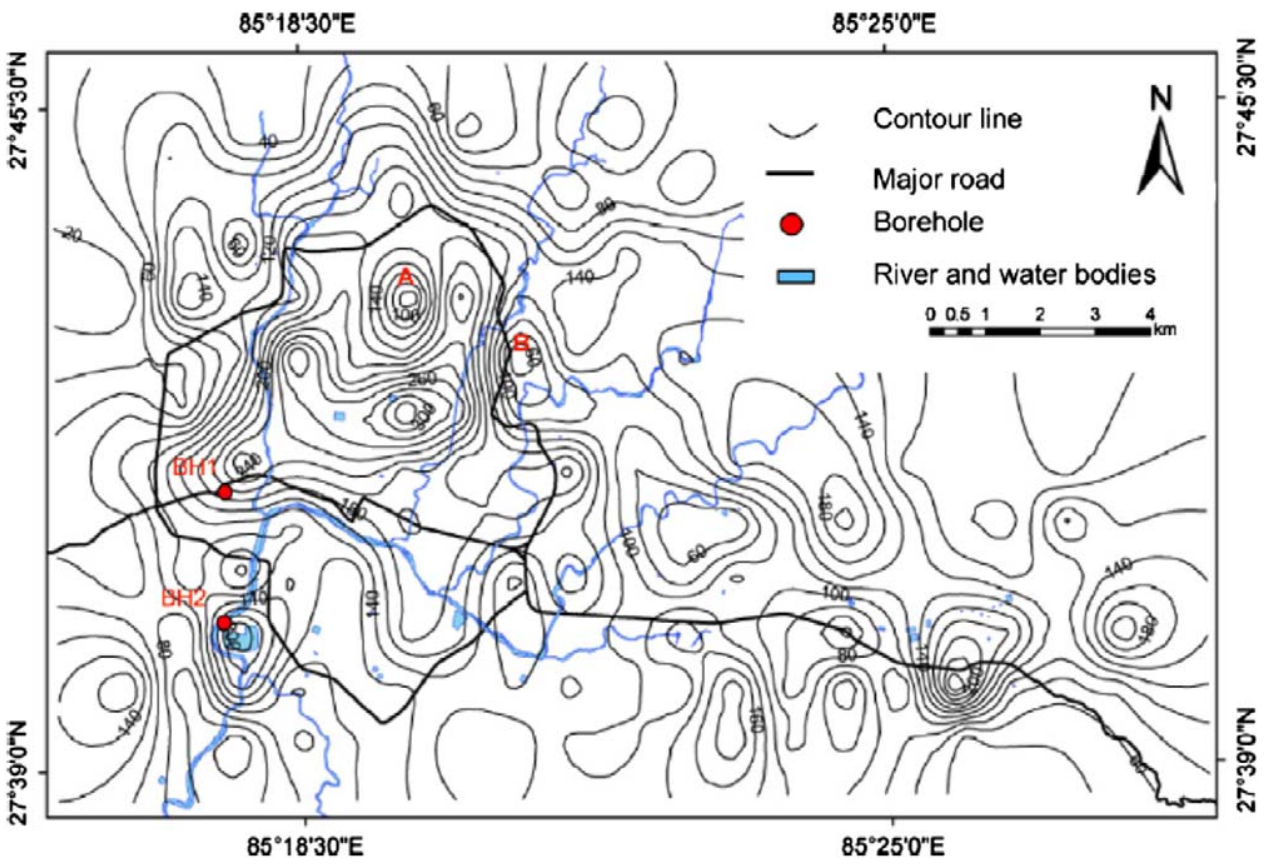

Figure 1. Contour map of the basement topography of the Kathmandu basin (from Paudyal et al. 2012b).

\section{STRONG-MOTION RECORDS}

Following the 2011 Himalayan earthquake in the Kathmandu Valley, the Central Department of Geology (CDG) at Tribhuvan University (TU) installed four Mitsutoyo JEP-6A3-2 accelerometers in collaboration with Hokkaido University, Japan (Bijukchhen et al. 2017). The strong-motion stations have a $100-\mathrm{Hz}$ sampling rate and are operated on continuous recording mode. According to Bijukchhen et al. (2017), one of the strongmotion stations, KTP, was installed on a rock outcrop at the Kirtipur Municipality Office, and the other three accelerometers (TVU, PTN, and THM) were installed on sediments, along an east-west (EW) linear array across the valley. No shear wave velocity measurements characterizing the site conditions of the stations have been published, however. In addition to the above instruments, the USGS installed one (GeoSIG NetQuakes) 200-Hz accelerometer on sediments (Dixit et al. 2015). The Department of Mines and Geology also operated a strongmotion instrument in central Kathmandu, which also recorded the 2015 sequence (Bhattarai et al. 2015). The code names and locations of all stations are shown in Figure 3. In this paper, we analyze ground motions at these stations from the 25 April 2015 M7.8 Gorkha earthquake, the 12 May 2015 M7.3 Dolakha earthquake, and two smaller aftershocks: the 26 April 2015 M6.7 and the 25 April 2015 M6.6 events (Figure 3).

The epicenters of the M7.8 Gorkha main shock and M6.6 25 April 2015 aftershock were located approximately $80 \mathrm{~km}$ northwest of the Kathmandu Valley, while the epicenters of the M7.3 and 26 April 2015 M6.7 aftershocks were located approximately $80 \mathrm{~km}$ northeast 


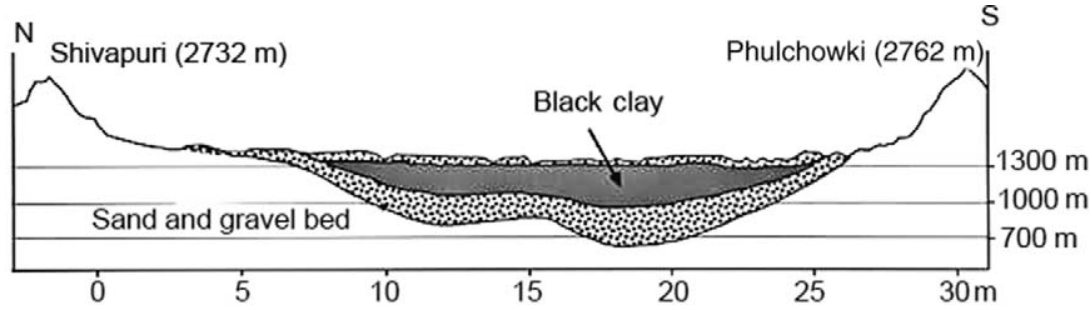

(a)

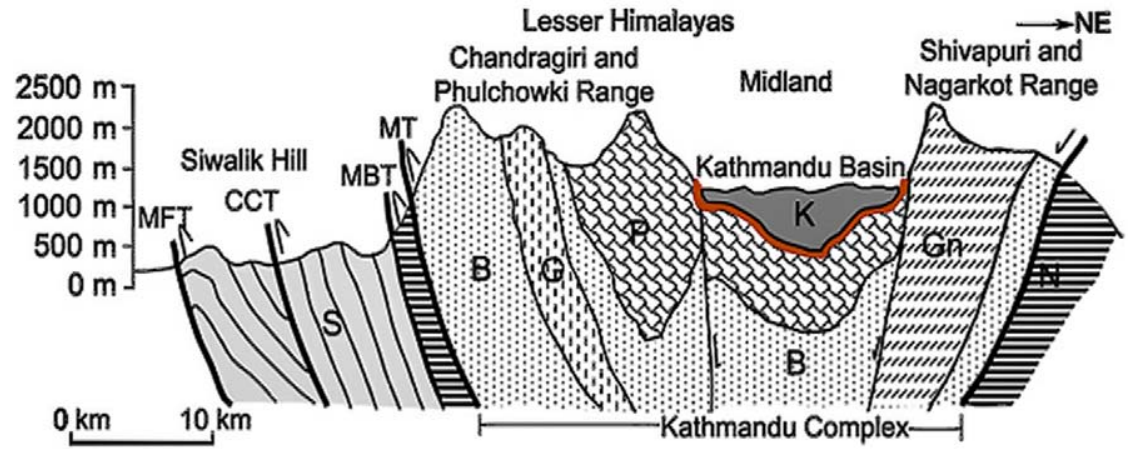

(b)

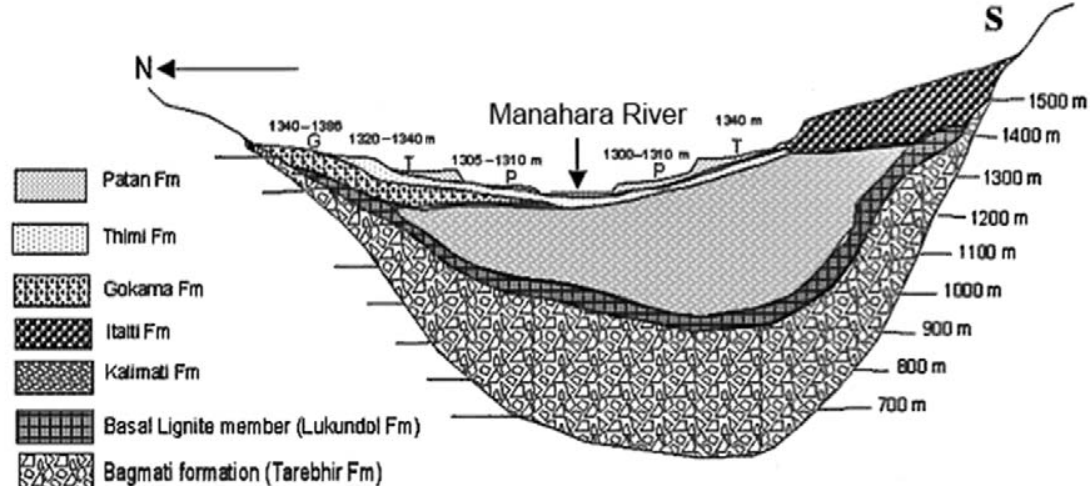

(c)

Figure 2. (a) Simplified cross section of the valley indicating the thickness of the soft black clay by Sakai et al. (2001), (b) schematic geological cross section through Central Nepal by Stöcklin (1980). Capital letters correspond to the nomenclature developed by Sakai et al. to describe the Kathmandu basin geology: S: Siwalik Group, B: Bhimphedi Group, P: Phulchowki Group, N: Nawakot Complex, G: Granite, Gn: Gneiss Complex, K: Kathmandu Complex, MFT: Main Frontal Thrust, CCT: Central Churia Thrust, MBT: Main Boundary Thrust, MT: Mahabharat Thrust. Further details can be found in Mugnier et al. (2011), (c) schematic of the Kathmandu Valley sediment deposits, reflecting the sedimentation processes (Moribayashi and Maruo 1980). 


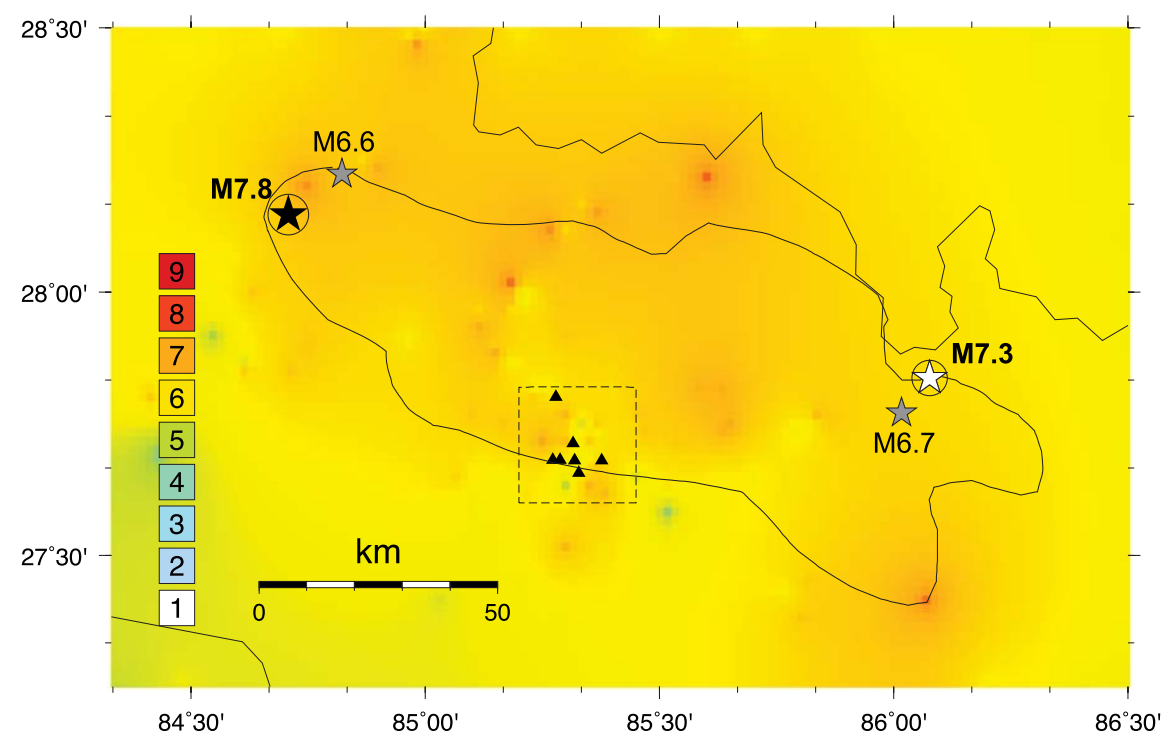

(a)

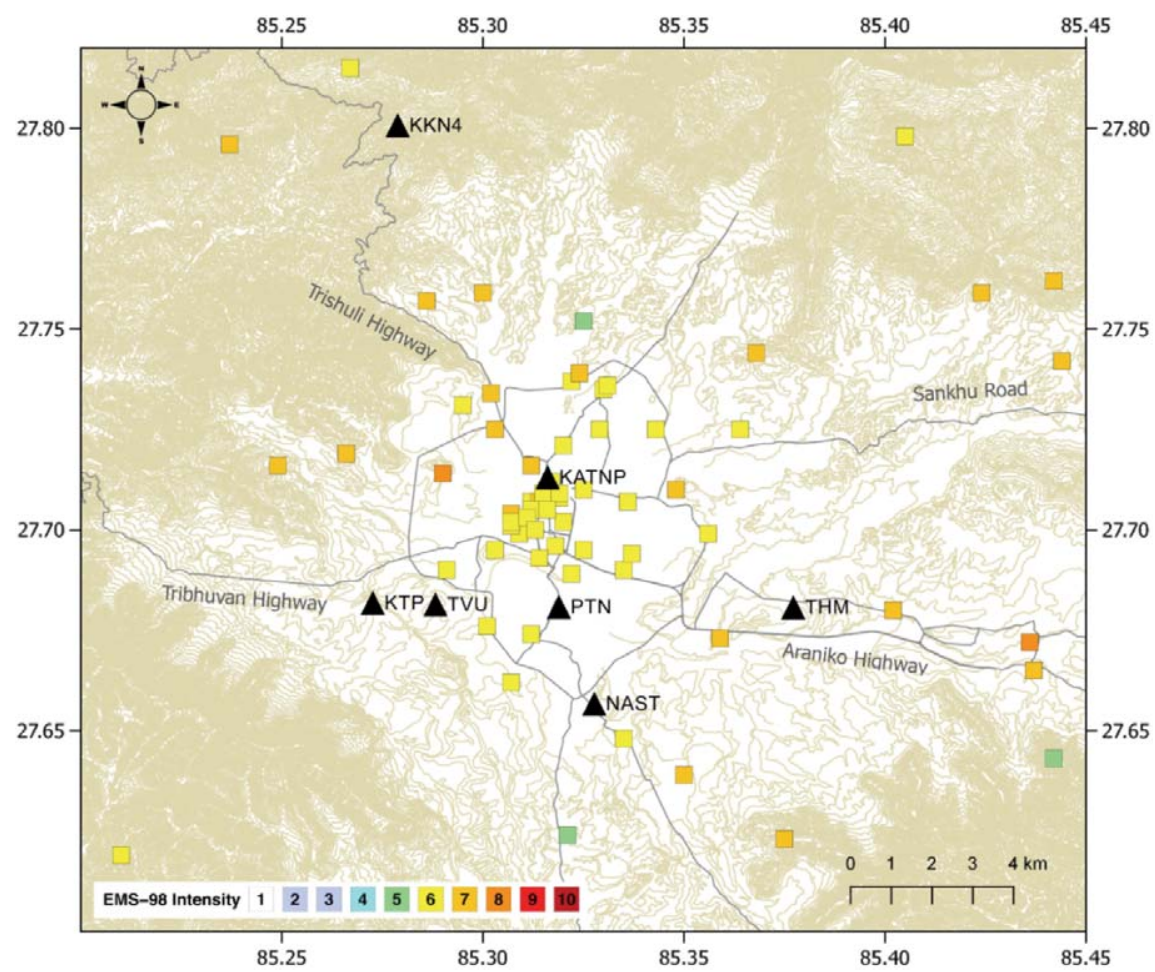

(b)

Figure 3. (top) Map depicting the epicenters of the 25 April 2015 M7.8 Gorkha and M6.6 25 April 2015 west of the valley and the 12 May 2015 M7.3 Dolakha and 26 April 2015 M6.7 earthquakes on the east, as well as an approximate surface projection of the M7.8 main shock source; (bottom) inset of Figure 3a indicated with dashed lines, showing the Kathmandu Valley and the locations of the five strong-motion stations and two GPS stations used in this study. Intensities are based on Martin et al. (2015) and figure has been adapted from Rajaure et al. (2016). 
of the valley. These events were also recorded by the two high-rate GPS stations shown in Figure 3, namely KKN4 (installed on a rock outcrop) and NAST (installed on the valley sediments). The main shock and Dolakha aftershocks occurred on the MHT (Avouac et al. 2015) with mechanisms that are consistent with previously published fault plane solutions (Sheehan et al. 2008, de la Torre et al. 2007, Rajaure et al. 2013).

Station KTP is located right outside the basin edge and is as close to a reference station as one could expect from such a sparsely instrumented region; station TVU is located on shallow sediments next to the basin edge, and we thus expect its ground motions to be affected by strong focusing effects and multiple high frequency reverberations; stations KATNP and PTN are located on the deepest part of the basin, where the depth of sediments is approximately $250 \mathrm{~m}$, according to Paudyal et al. (2012b). Finally, THM is located on shallower sediments near the opposite edge of the basin relative to TVU, but much further away from the source. We thus expect high frequencies carried by surface waves to be attenuated at THM during the main shock relative to the strong-motion stations located closer to the epicenter.

Acceleration time series and PGAs for all strong-motion stations and the two strongest events are indicated on Figure 4. The rock-outcrop (reference) station of the array, KTP, recorded the maximum horizontal ground acceleration during the M7.8 main shock $\left(2.54 \mathrm{~m} / \mathrm{s}^{2}\right.$ in the EW direction); while the eastern-most station of the array, THM, recorded the maximum horizontal acceleration during the M7.3 aftershock $\left(1.66 \mathrm{~m} / \mathrm{s}^{2}\right.$ in the EW direction). Table 1 lists the coordinates, PGA, and velocity that each of the strong-motion stations recorded during the main shock.

The response spectral ratios of the ground motions recorded by the instruments on sediments relative to the corresponding motions at KTP for the M7.8 and M7.3 events are shown in Figure 5. One interesting observation is that moving from west to east parallel to the M7.8 rupture below the valley, the low period (high frequency) energy depicted as a spike at $0.3 \mathrm{sec}$ at station KTP gradually decays as the long-period amplification peak at $5 \mathrm{~s}$ emerges, most clearly at stations KATNP and THM. Note that the pattern of amplification at $5 \mathrm{~s}$ also appears in the M7.3 aftershock, albeit at lower amplitude, yet the low period $(<0.5 \mathrm{~s})$ components of ground motion in the valley are either preserved or amplified relative to the high frequency components at KTP. These observations suggest that the long-period amplification is a characteristic of the basin response, whereas the short period severe de-amplification of the main shock recordings on sediments was a characteristic of the specific event, which Rajaure et al. (2016) and Ampuero et al. (2015) attributed to a combination of source and nonlinear site effects. This point is further elaborated upon in the next section of the paper.

\section{SITE AMPLIFICATION: OBSERVATIONS AND PREDICTIONS}

We next use the strong-motion records of the main shock and three aftershocks to investigate site response relative to the reference rock site. The most striking characteristics of the ground motions at the four soil sites (TVU, PTN, THM, and KATNP) are the large amplitude surface waves that dominate the time series and their severely attenuated high frequency content. Figure 6 shows the Fourier amplitude spectral ratios of the horizontal components (vector summation of north-south and EW components) of the soil stations relative to the rock station (KTP). Figure 6 shows the systematic strong amplification of all ground motions 


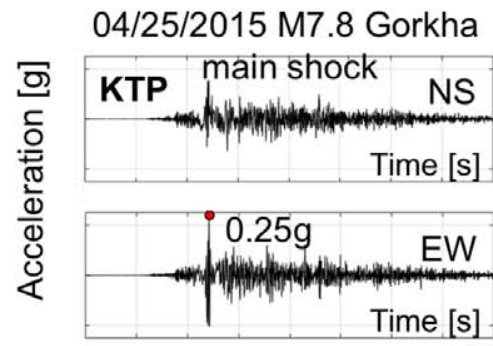

05/12/2015 M7.3 Dolakha
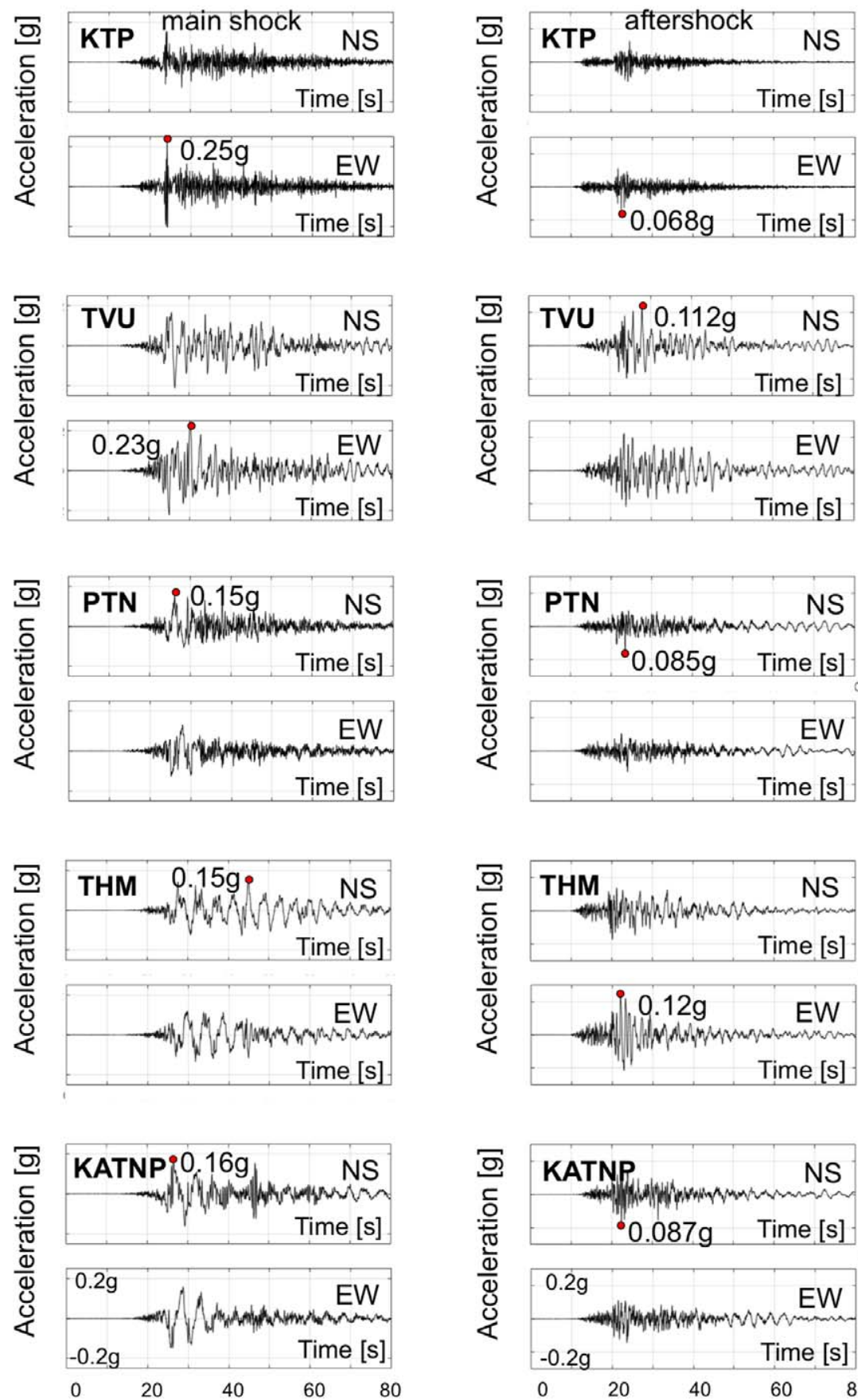

Figure 4. NS and EW components of the 25 April 2015 M7.8 Gorkha (left) and the 12 May 2015 M7.3 Dolakha (right) earthquakes, recorded at the five strong-motion stations. 
Table 1. Strong-motion stations, location, and peak ground acceleration (PGA) and velocity (PGV) recorded during the M7.8 main shock

\begin{tabular}{|c|c|c|c|c|c|c|}
\hline Station & $\begin{array}{c}\text { Site } \\
\text { Conditions }\end{array}$ & $\begin{array}{l}\text { Latitude } \\
\text { (N) }\end{array}$ & $\begin{array}{l}\text { Longitude } \\
\text { (E) }\end{array}$ & Location & PGA & $\begin{array}{l}\mathrm{PGV} \\
\mathrm{cm} / \mathrm{s}\end{array}$ \\
\hline KTP & Rock & 27.68182 & 85.27261 & $\begin{array}{l}\text { Kirtipur Municipality } \\
\text { Office }\end{array}$ & $0.260 \mathrm{~g}$ & 52 \\
\hline TVU & Soil & 27.68145 & 85.28821 & $\begin{array}{l}\text { Central Department of } \\
\text { Geology }\end{array}$ & $0.234 \mathrm{~g}$ & 99 \\
\hline PTN & Soil & 27.68082 & 85.31897 & $\begin{array}{l}\text { Engineering College, } \\
\text { Pulchowk }\end{array}$ & $0.154 \mathrm{~g}$ & 74 \\
\hline THM & Soil & 27.68072 & 85.3772 & $\begin{array}{l}\text { University Grant } \\
\text { Commission Office, } \\
\text { Bhaktapur }\end{array}$ & $0.154 \mathrm{~g}$ & 90 \\
\hline KATNP & Soil & 27.71307 & 85.3161 & Kantipath & $0.163 \mathrm{~g}$ & 110 \\
\hline
\end{tabular}

on soil compared with that on rock outcrop over a wide range of frequencies (approximately 0.1-2 Hz), and de-amplification of the frequency components larger than approximately $2 \mathrm{~Hz}$. In the same figure, we also observe that site amplification functions are characterized by three or more prominent peaks at approximately the same frequency range across all stations. This observation strongly suggests that all four soil stations (and likely by extension, the basin sediments) are dominated by three common amplification mechanisms. In addition, we observe that, systematically, site response during the M7.8 and M7.3 events is shifted to lower frequencies and has lower amplitude than the response to the M6.6 and M6.7 events, respectively_results that suggest that the site response during the stronger events was nonlinear (Dixit et al. 2015, Rajaure et al. 2016).

We next consider the rotation independent response spectral acceleration RotD50 (Boore 2010) of the M7.8 main shock and M7.3, M6.7, and M6.6 aftershocks against response spectra predicted using a series of ground motion prediction equation (GMPEs). For this comparison, we have assumed time-averaged shear wave velocity of the top $30 \mathrm{~m} V_{S 30}=200 \mathrm{~m} / \mathrm{s}$ for the soil sites (JICA 2002). Selecting a GMPE to compare our recordings against was a contested part of our research: given the seismotectonic environment in Nepal, a subduction zone GMPE would have been best. Among the available choices, we initially considered the 2015 update to BC Hydro (Abrahamson et al. 2016), which is "global," has reasonable data coverage for the magnitude-distance range of interest, and accounts for nonlinear response; however, it does not have data from the Himalayas, which makes it impossible to evaluate its credibility based on one earthquake sequence. And while the closest option geographically is Sharma et al. (2009), validating our implementation of their equations was unsuccessful.

On the other hand, although the Boore et al. (2014) equations (BSSA14) for active crustal regions provide a reasonable analog for Nepal, strong-motion data from the Himalayan region are sparse. Comparison of all four events to BSSA14 at all stations reveals that ground motions on soil are severely depleted of high frequency (short-period) energy relative to predicted levels for M7.8 (Figure 7). Note that this high frequency anomaly of the main 

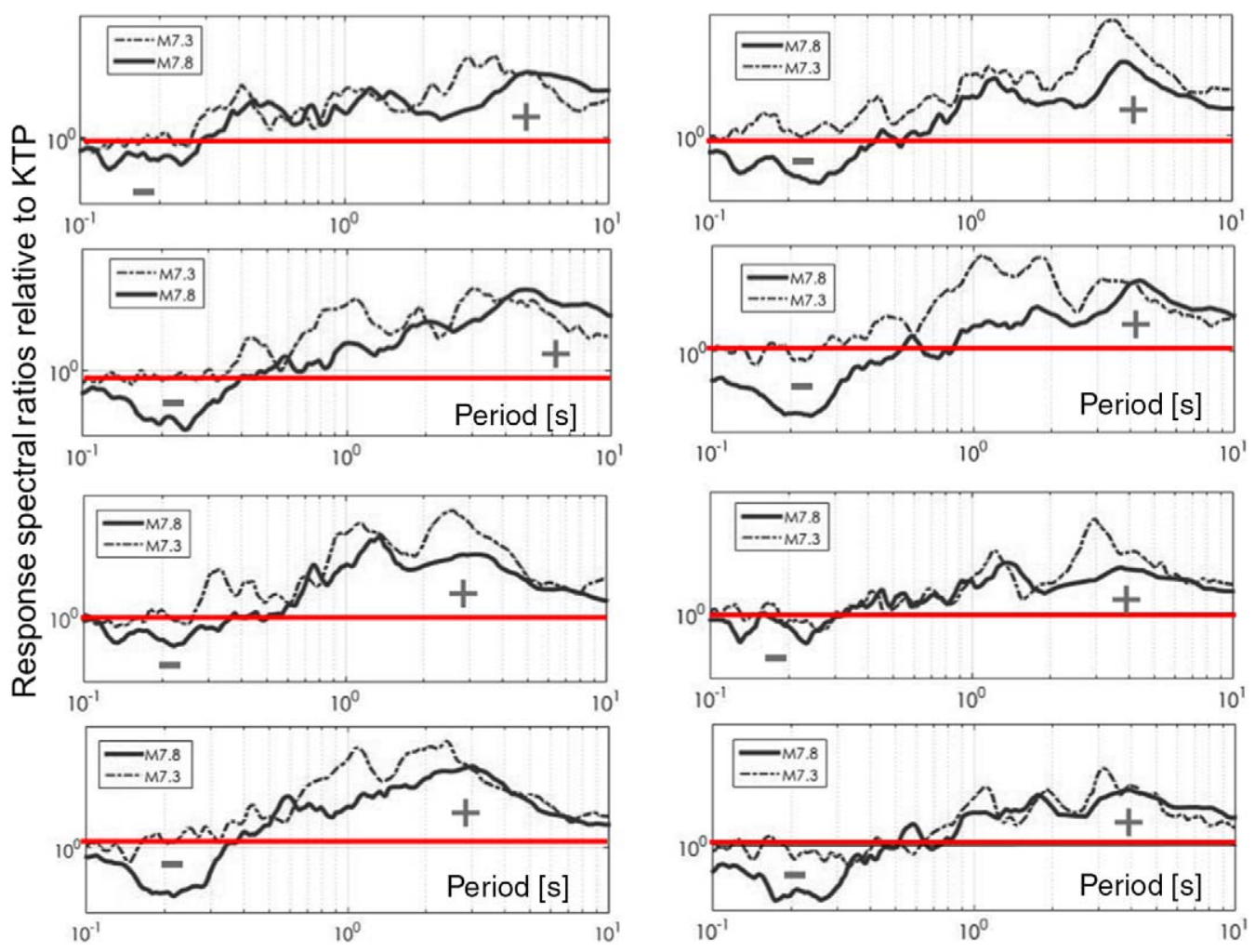

Figure 5. Response spectral ratios of the NS and EW components of the 25 April 2015 M7.8 Gorkha main shock and 12 May 2015 M7.3 Dolakha relative to the rock outcrop station, KTP.

shock here used to describe frequencies higher than $2 \mathrm{~Hz}$ in accordance to the seismological community's convention. It is pronounced both in the records on sediments and the records at the reference site, KTP (Figure 7), suggesting that the depletion of high frequency effects is at least in part due to source and/or path effects rather than site effects alone.

Rajaure et al. (2016) suggested that this effect could be in part explained because the high frequency energy in this earthquake was not uniformly distributed across the ruptured area. Imaged by Avouac et al. (2015), the high frequency energy was shown to originate from the down-dip end of the rupture that was also the furthest from the Kathmandu basin. On the same time, ground motion prediction equations such as Boore et al. (2014) are generally based on the nearest distance to the rupture, and this simple parameterization of distance cannot account for details such as the location of the high frequency energy. When Asimaki et al. (2017) compared the Gorkha main shock ground motions to the Boore et al. (2014) predictions, assuming that the distance to the surface projection of the fault was $R_{j b}=35 \mathrm{~km}$ rather than $0 \mathrm{~km}$, they found that the observed high frequency (short-period) amplitudes closely matched the GMPE spectra predicted by using the distance to the high frequency energy sources, while the observed low frequency (long-period) amplitudes more closely 

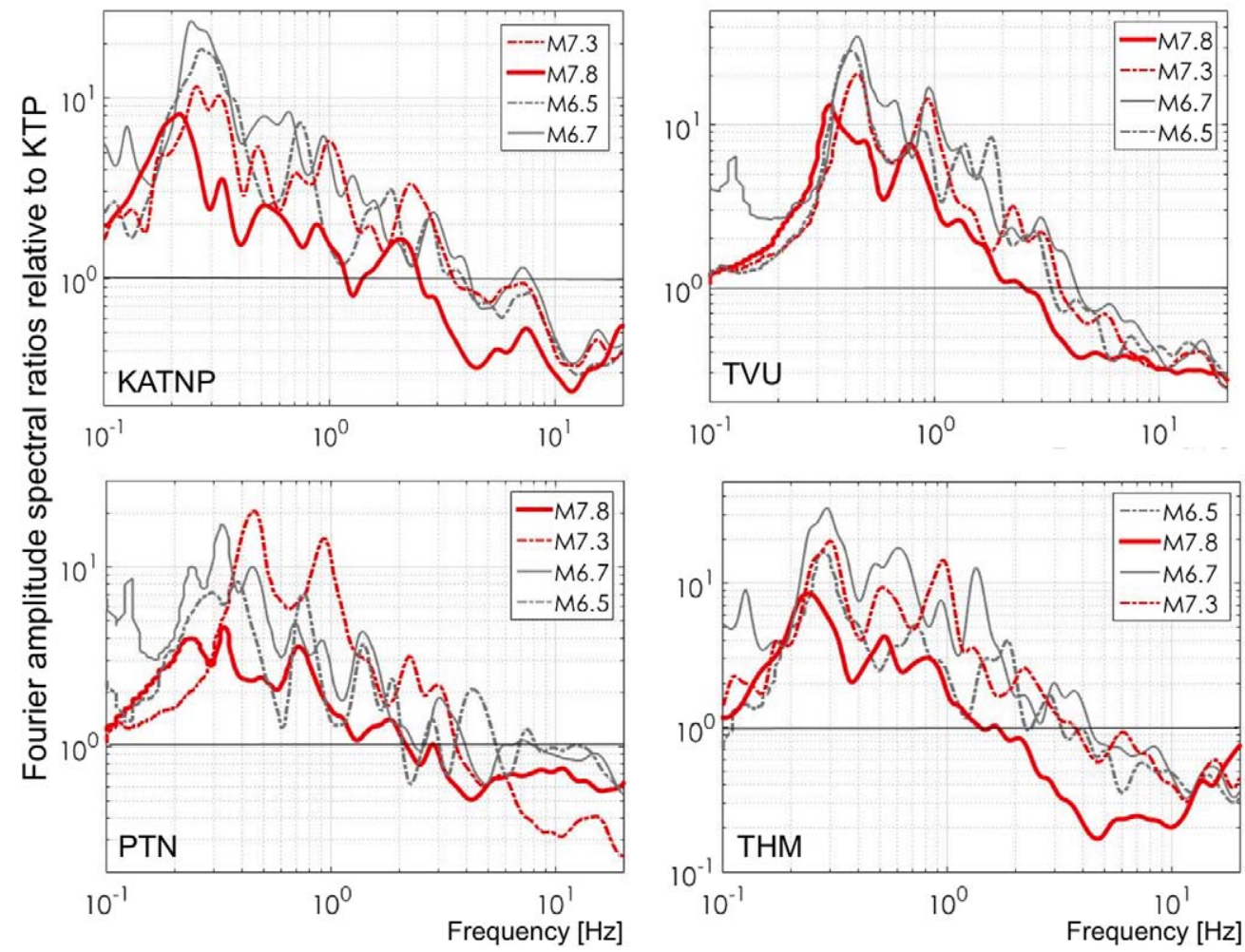

Figure 6. Fourier amplitude spectral ratios at the stations on soil relative to KTP. The systematic shift of the site response peaks to lower frequencies during the stronger events, as well as the reduction in amplitude are clear manifestations of nonlinear response. At each site, nonlinearity is observed at several frequencies (red vertical lines). We hypothesize that the ubiquitous lower frequency peak at $0.25 \mathrm{~Hz}$ represents amplification due to basin edge generated surface waves, while the middle and highest frequency peaks represent each amplification of the deeper and shallow soft soil layers, respectively.

matched the GMPE for $R_{j b}=0 \mathrm{~km}$. While purely qualitative, results from this exercise suggest that GMPEs in the future should examine the separate parameterization of low and high frequencies, particularly for large magnitude events and near-field motions.

\section{BASIN EFFECTS: OBSERVATIONS AND IDEALIZED SIMULATIONS}

In the absence of more credible information on the velocity profile at depth, we next examine the role basin effects and their correlation to the structural damage and ground failure in Kathmandu by an idealized experiment. Assuming $V_{S 30}=200 \mathrm{~m} / \mathrm{s}$, a bounded exponential increase in stiffness with confining pressure (Vrettos 1990) and a basement rock with shear wave velocity $1,000 \mathrm{~m} / \mathrm{s}$ (ensuring velocity contrast 2.0 for the $250-\mathrm{m}$ deep sedimentary basin and 1.5 for the $500-\mathrm{m}$ deep basin), the fundamental mode of the soil 
column at the deepest location of the basin ranges between 1.5-3 s (or $0.33-0.67 \mathrm{~Hz}$ ) for a range of maximum thickness of 250-500 $\mathrm{m}$ (Rajaure et al. 2016). While the latter is close to the predominant frequency of the singular pulse at KTP that was amplified and reverberated across the valley (Figure 4), the range of predicted fundamental mode frequencies reflects the uncertainty regarding the detailed structure of the Kathmandu Valley revealed among others by Paudyal et al. (2012a, b). We should mention here that the lowest amplification frequency observed by Paudyal et al. $(2012 \mathrm{a}, \mathrm{b})$ at 172 sites in the valley was $0.48-0.58 \mathrm{~Hz}$, which - although not far from our estimates of fundamental mode using strong motion records - bears the uncertainties associated with microtremor analysis and the physical meaning of the peak frequency of $\mathrm{H} / \mathrm{V}$ ratios.

The predicted frequencies of one-dimensional (1-D) site response described previously, however, do not take into account two-dimensional (2-D) and 3-D wave propagation effects. While the Kathmandu Valley is shallow with a depth/width ratio $(d / w)$ on the order of 0.1 , and the predominant frequency of converted surface waves should, theoretically, be close to the predicted 1-D (quarter-wavelength) frequency

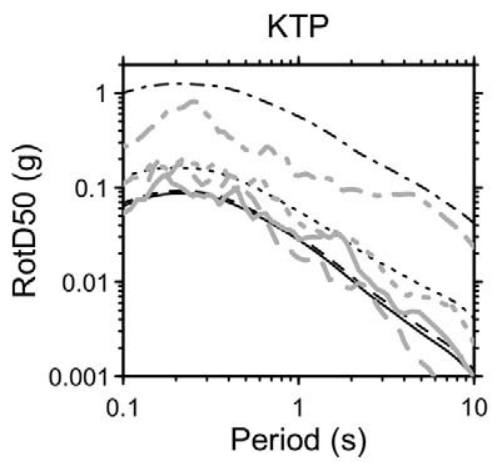

THM

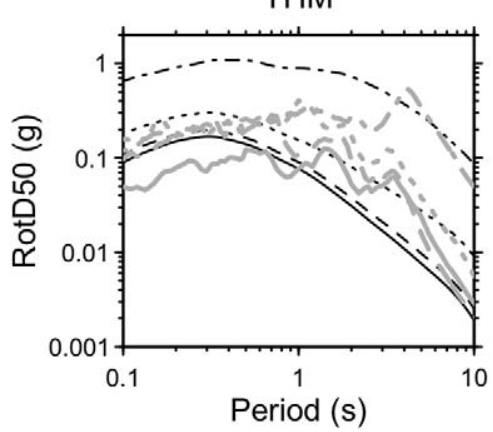

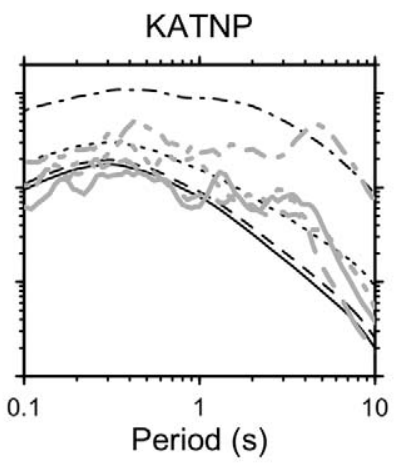

TVU

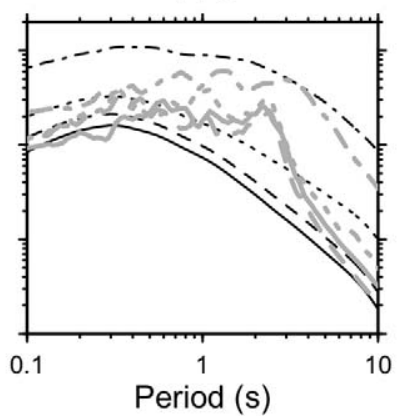

PTN
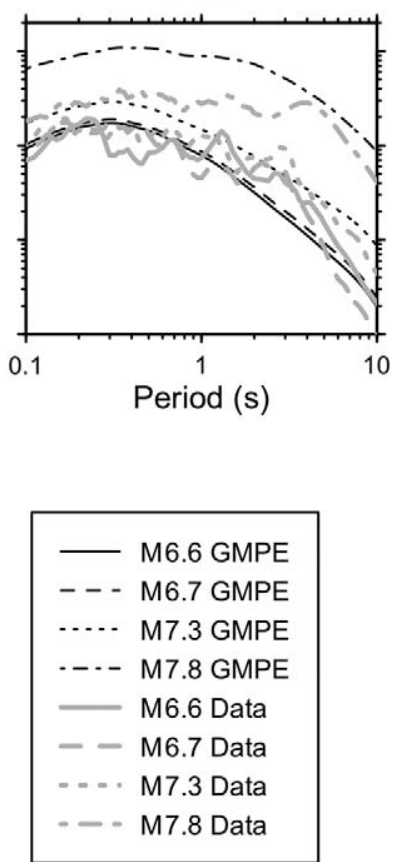

Figure 7. Orientation independent response spectral acceleration (RodD50) of the M7.8 Gorkha earthquake and the M7.3, M6.7 and M6.6 aftershocks recorded at the five strong-motion stations compared with the BSSA14 GMPE (Boore et al. 2014). We assume the time-averaged shear wave velocity in the upper $30 \mathrm{~m}\left(V_{S 30}\right)$ is $750 \mathrm{~m} / \mathrm{s}$ for the rock (reference) site, and $200 \mathrm{~m} / \mathrm{s}$ for the soil sites, based on a small number of shear wave velocity profiles published by JICA (2002). 
(see Hashash et al. 2016, based on Bard and Bouchon 1985, Harmsen and Harding 1981), one expects the lower modal frequencies to be strongly affected by body-to-surface wave mode conversion at the basin edges and lateral reverberations of the surface waves across the valley. To see these effects, we next performed another simplified numerical experiment, this time in 2-D.

We constructed an idealized trapezoid cross section of the valley with a depth of $250 \mathrm{~m}$ and homogeneous soil, intended as a proxy to the response of the black clay (Figure 2a). We subjected the numerical valley to vertically propagating off plane shear waves, using Ricker pulses to control the frequency content of the seismic shaking. The seismogram synthetic for an incident pulse with central frequency $0.1 \mathrm{~Hz}$, which captures the frequency range between $0.05 \mathrm{~Hz}$ and $0.3 \mathrm{~Hz}$, is shown in Figure 8a. One can clearly see that the singular pulse arriving on the rock outcrop surface gets trapped in the soft sedimentary structure of the basin, and every time it reverberates, it produces surface waves (here, Love waves) that travel toward the center of the valley. Comparing the idealized response in Figure 8a with the filtered ground motions recorded by the GPS and strong-motion stations in the same frequency range in Figure 8c, we recognize the singular pulse at stations KTP and KKN4 on rock outcrop, and the reverberating pulses at the deeper sections of the basin (stations KATNP, NAST, and THM) are composed of vertically reverberating shear waves and horizontally traveling surface waves. Tracing the peak acceleration amplitude on the surface of the basin relative to the rock outcrop, we see that the peak acceleration on the sediments is three times larger than the acceleration on rock outcrop (Figure 8b), an effect that we also qualitatively see by comparing the amplitude of the recorded pulses in Figure 8c.

Repeating the same experiment in Figure 9, this time with a higher frequency Ricker pulse $(0.5-3 \mathrm{~Hz})$, we observe a completely different reverberation pattern: the incident pulse again gets trapped in the sediments, but takes much longer to reflect and refract between the basement rock and the surface, and thus the direct arrivals and surface waves only superimpose near the basin edge. The result is shown in Figure 9b, where the amplitude of the acceleration is three times that of rock outcrop next to the basin edge and rapidly drops to 1.75 across the basin. The large amplification at the basin edges is quantitatively evident from the filtered ground motion time series in Figure 9c, as well as from macroseismic observations, such as the liquefaction evidence near the south-east basin edge of Bungamati, as shown in Figure 9b.

The higher modes $(>4 \mathrm{~Hz})$ are too complex to capture by a simple simulation like shown earlier because they are highly sensitive to the heterogeneities and non-uniform geometry of the basement rock, as well as to the nonlinear response of the near-surface sediments on which we were able to find no information at all. Regardless of the exact mechanism, the higher frequencies were strongly de-amplified during the main shock and 12 May 2015 aftershock. Thankfully, this very frequency range coincided with the frequency characteristics of the ubiquitous 1-2 story buildings in Kathmandu, an observation corroborated by the arguably low levels of damage in the valley given the magnitude of the event and the proximity of Kathmandu to the fault rupture. The low intensity was predicted by the early ground shaking characterization released by the USGS (Hayes et al. 2015), and confirmed by lower intensities in central Kathmandu Valley compared with adjacent foothills (Martin et al. 2015). 


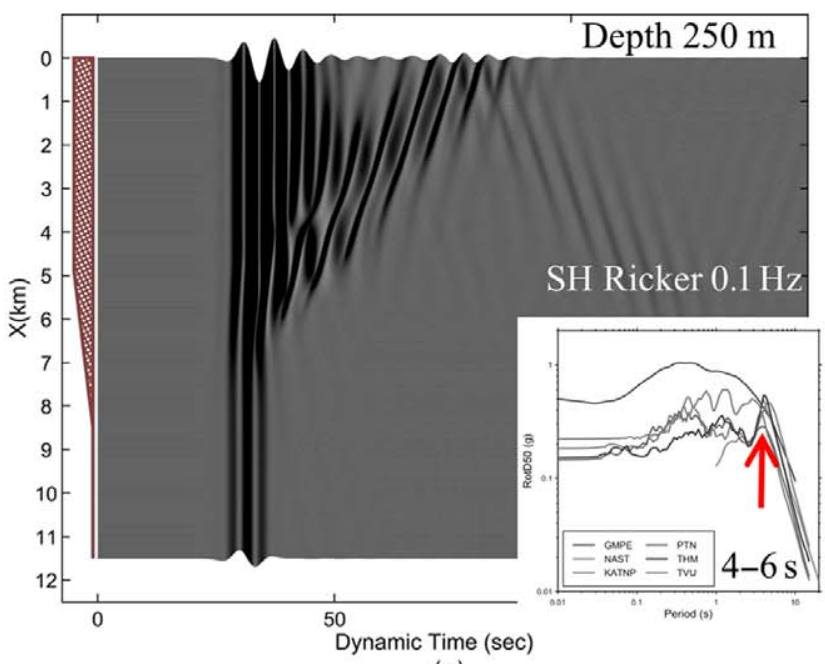

(a)

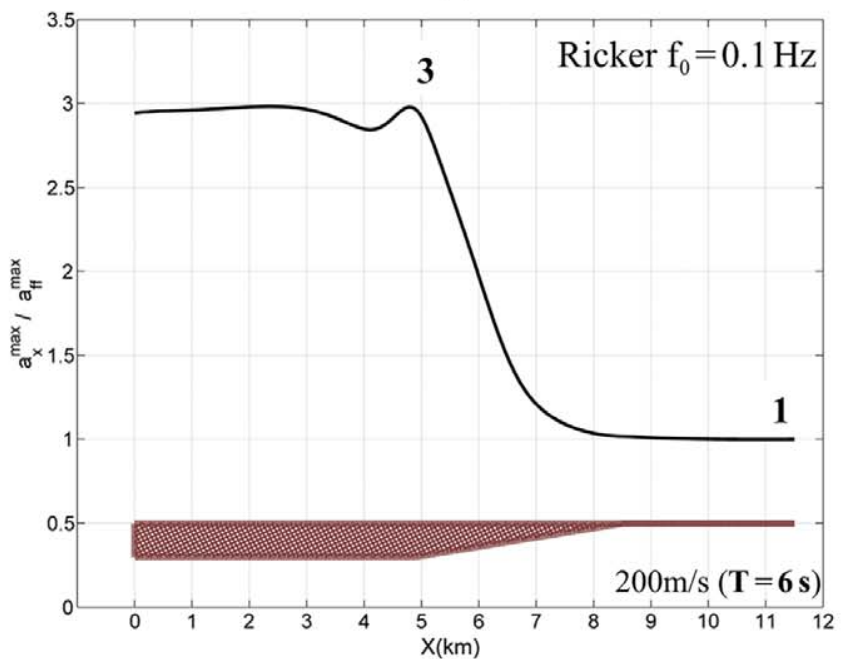

(b)
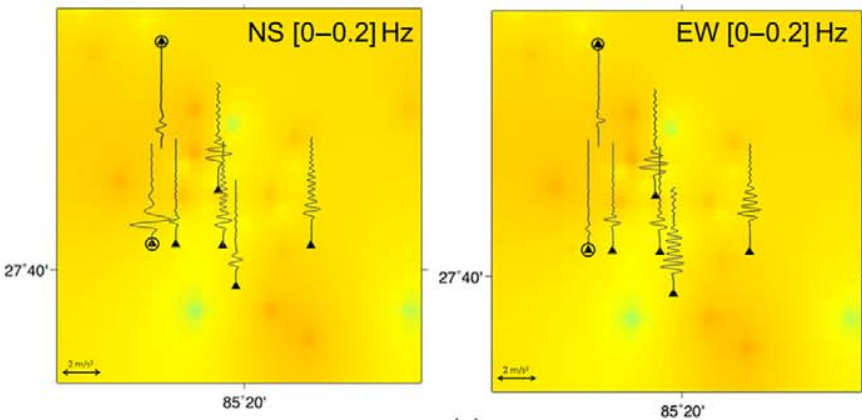

(c)

Figure 8. Simulation versus observations of long-period $(<0.2 \mathrm{~Hz})$ off plane shear wave amplification in an idealized simulation of the Kathmandu basin 2-D site effects: (a) seismogram synthetics in response to an incident SH Ricker pulse of central frequency $0.1 \mathrm{~Hz}$, (b) ground surface amplification of peak acceleration relative to the basin rock-outcrop, and (c) low-pass filtered ground motion data in the $0-0.2 \mathrm{~Hz}$ frequency range. 


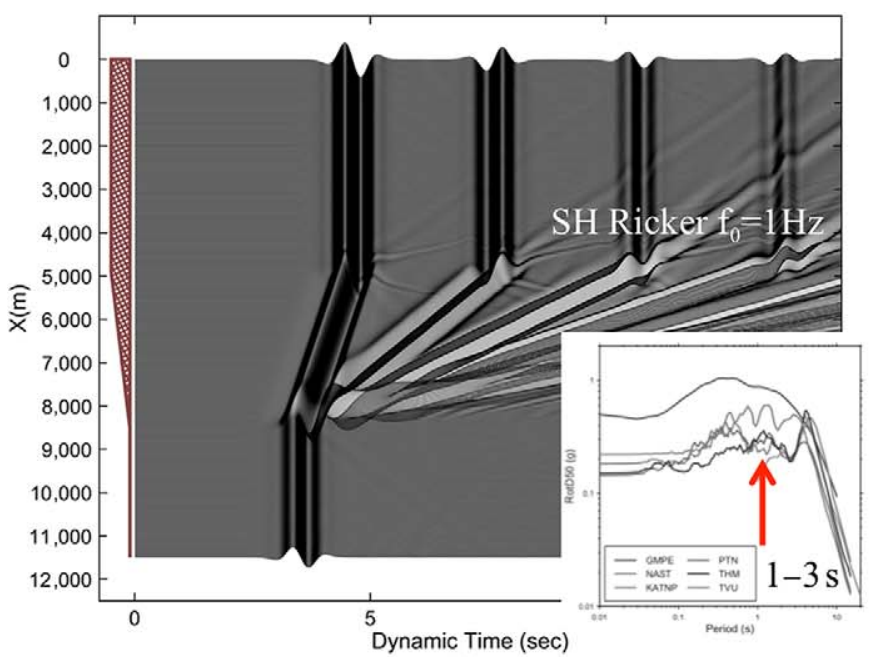

(a)

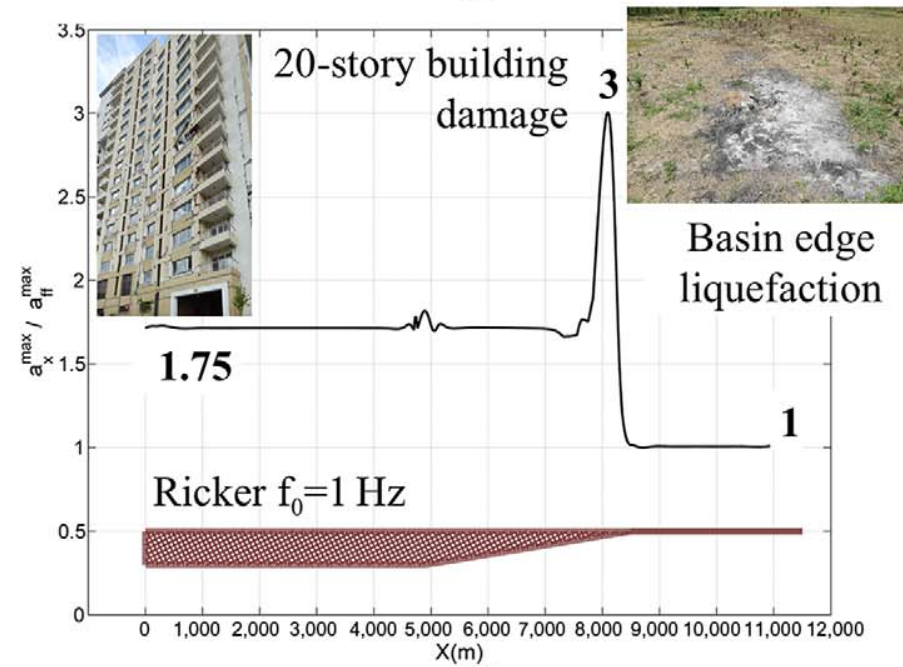

(b)
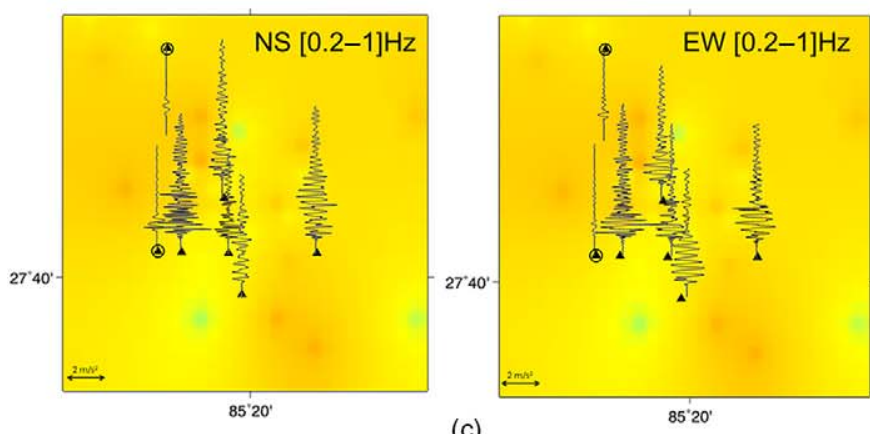

(c)

Figure 9. Simulation versus observations of $0.5-3 \mathrm{~Hz}$ off plane shear wave amplification in an idealized simulation of the Kathmandu basin 2-D site effects: (a) seismogram synthetics in response to an incident SH Ricker pulse of central frequency $1.0 \mathrm{~Hz}$, (b) ground surface amplification of peak acceleration relative to the basin rock-outcrop, and (c) band-pass filtered ground motion data in the $0.2-1 \mathrm{~Hz}$ frequency range. 


\section{CONCLUSIONS}

In this paper, we analyzed the main shock and three aftershocks of the Gorkha earthquake sequence, as recorded by five strong-motion instruments and two GPS stations. These records revealed a mixture of features that have been frequently observed in similar settings, such as nonlinear response and strong amplification of long-period energy within the sedimentary basin. The strong motions of the main shock were severely depleted of high frequency energy, a feature that can be in part explained by the confinement of the high frequency radiation sources at the deeper portion of the fault, which is on the distant side of the fault relative to Kathmandu Valley.

Site effects likely played a dominant role in shaping the amplitude and frequency content of ground shaking on soil. Strong motions on soil for all four events showed systematic amplification relative to the rock site in the low frequency range $(0.1-2.5 \mathrm{~Hz})$, and de-amplification of higher frequencies $(>2.5 \mathrm{~Hz})$. On the same time, the soil-to-rock amplification ratio of the main shock and the M7.3 aftershock had lower amplitude and lower resonant frequencies compared with two (M6.6 and M6.7) moderate events, which strongly suggested that the site response during the stronger events was nonlinear. While some of the observed site amplification characteristics could be interpreted using a 1-D site response analyses, to fully understand the complexity of waveforms and the amplitude and frequency shift in our main shock observations relative to the weaker ground motions, one would need to carry through nonlinear numerical analyses of 3-D basin response, including the rupture that propagated through the basement rock of the basin from west to east.

We also demonstrated that using simplified models of basin response, one can shed qualitative light on the constructive interference between reverberating shear and surface waves in the basin for the longer periods, and can capture the amplification patterns of these wave components that agree with macroseismic observations (e.g., taller building damage or basin edge evidence of liquefaction). This not possible to achieve for higher frequencies $(>3 \mathrm{~Hz})$ that are very sensitive to the soil heterogeneity, basement geometry complexity, and nonlinear site response. Given the significance of seismic hazard in the Himalayas and the rapidly developing infrastructure in Kathmandu, future research should focus on obtaining and compiling field information and laboratory testing, installing permanent strong-motion stations and downhole arrays to understand the unique dynamic soil properties of black clay, and integrating the information with ground motion simulation models to develop region-specific hybrid seismic hazard maps.

\section{ACKNOWLEDGMENTS}

The accelerometer record at station KATPN was provided by the USGS. The main shock data at stations KTP, PTN, TVU, and THM can be downloaded from: http://www. strongmotioncenter.org/cgi-bin/CESMD. The aftershock time series should be made available soon through the same portal. We acknowledge partial support of this work from the USGS/Caltech Cooperative Agreement (sponsor award number: G14AC00109), and from the GEER Association. 


\section{REFERENCES}

Abrahamson, N., Gregor, N., and Addo, K., 2016. BC Hydro ground motion prediction equations for subduction earthquakes, Earthquake Spectra 32(1), 23-44.

Asimaki, D., Thompson, E. M., Rajaure, S., Hough, S. E., Ampuero, P., and Martin, S., 2017. Source, basin, and site effects in strong motion records of the 2015 Gorkha Earthquake, in Proceedings of the 16th World Conference on Earthquake Engineering, Santiago Chile, 12-16 January 2017, Paper No 609.

Avouac, J.-P., Meng, L., Wei, S., Wang, T., and Ampuero, J.-P., 2015. Lower edge of locked Main Himalayan Thrust unzipped by the 2015 Gorkha Earthquake, Nature Geosciences 8(9), 708-711.

Bard, P. Y., and Bouchon, M., 1985. The two-dimensional resonance of sediment-filled valleys, Bulletin of the Seismological Society of America 75(2), 519-541.

Bhattarai, M., Adhikari, L. B., Gautam, U. P., Laurendeau, A., Labonne, C., Hoste-Colomer, R., Sèbe, O., and Hernandez, B., 2015. Overview of the large 25 April 2015 Gorkha, Nepal, earthquake from accelerometric perspectives, Seismological Research Letters 86(6), 1540-1548.

Bilham, R., Gaur, V. K., and Molnar, P., 2001. Himalayan seismic hazard, Science 293(5534), $1442-1444$.

Bijukchhen, S. M., Takai, N., Shigefuji, M., Ichiyanagi, M., Sasatani, T., and Sugimura, Y., 2017. Estimation of 1-D velocity models beneath strong-motion observation sites in the Kathmandu Valley using strong motion records from moderate-sized earthquakes, Earth, Planets and Space 69(1), 97.

Bollinger, L., Sapkota, S. N., Tapponnier, P., Klinger, Y., Rizza, M., Van Der Woerd, J., Tiwari, D. R., Pandey, R., Bitri, A., and Bes de Berc, S., 2014. Estimating the return times of great Himalayan earthquakes in eastern Nepal: evidence from the Patu and Bardibas strands of the Main Frontal Thrust. Journal of Geophysical Research Solid Earth 119(9), 7123-7163.

Boore, D. M., 2010. Orientation-independent, nongeometric-mean measures of seismic intensity from two horizontal components of motion, Bulletin of the Seismological Society of America 100(4), 1830-1835.

Boore, D. M., Stewart, J. P., Seyhan, E., and Atkinson, G. M., 2014. NGA-West2 equations for predicting PGA, PGV, and 5\% damped PSA for shallow crustal earthquakes, Earthquake Spectra 30(3), 1057-1085.

Chen, W-P., and Molnar, P., 1977. Seismic moments of major earthquakes and the average rate of slip in central Asia, Journal of Geophysical Research 82(20), 2945-2969.

Chitrakar, G. R., and Pandey, M. R., 1986. Historical earthquakes of Nepal, Bulletin of Nepal Geolological Society 4, 7-8.

Collins, B. D., and Jibson, R. W. (2015). Assessment of existing and potential landslide hazards resulting from the April 25, 2015 Gorkha, Nepal earthquake sequence, Report US Geological Survey, doi:10.3133/ofr20151142

de la Torre, T. L., Monsalve, G., Sheehan, A. F., Sapkota, S., and Wu, F., 2007. Earthquake processes of the Himalayan collision zone in eastern Nepal and the southern Tibetan Plateau, Geophysical Journal 171(2), 718-738.

Dixit, A., Dwelly-Samant, L., Nakarmi, M., Pradhanang, S., and Tucker, B., 1998. The Kathmandu Valley Earthquake management plan, National Society for Earthquake Technology-Nepal 38.

Dixit, A. M., Ringler, A. T., Sumy, D. F., Cochran, E. S., Hough, S. E., Martin, S. S., Gibbons, S., Luetgert, J. H., Galetzka, J., and Shrestha, S. N., 2015. Strong-motion observations of 
the M 7.8 Gorkha, Nepal, earthquake sequence and development of the N-SHAKE strongmotion network. Seismological Research Letters 86(6), 1533-1539.

Hagen, T., 1952. Preliminary Note on the Geological Structure of Central Nepal, Central Department of Geology, Tribhuvan University, Kathmandu, Nepal.

Harmsen, S., and Harding, S., 1981. Surface motion over a sedimentary valley for incident plane P and SV waves, Bulletin of the Seismological Society of America 71, 655-670.

Hashash, Y. M. A., Kieffer, D. S., Tiwari, B., Asimaki, D., Moss, R. E. S., Thompson, E. M., Acharya, I., Adhikari, B., Clahan, K. B., Collins, B. D., Dahal, S., Jibson, R. W., Khadka, D., Macdonald, A., Madugo, C. L. M., Mason, H. B., Pehlivan, M., Rayamajhi, D., and Uprety, S., 2016. Geotechnical Field Reconnaissance: Gorkha (Nepal) Earthquake of April 252015 and Related Shaking Sequence, Report of the National Science FoundationSponsored Geo-engineering Extreme Events, Reconnaissance (GEER) Team. doi:10. $18118 / \mathrm{G} 61591$.

Hayes, G. P., Briggs, R. W., Barnhart, W. D., Yeck, W. L., McNamara, D. E., Wald, D. J., Nealy, J. L., Benz, H. M., Gold, R. D., and Jaiswal, K. S., 2015. Rapid characterization of the $2015 \mathrm{Mw} 7.8$ Gorkha, Nepal, earthquake sequence and its seismotectonic context, Seismological Research Letters, 86(6), 1557-1567.

Japan International Cooperation Agency (JICA), 2002. The study on earthquake disaster mitigation in the Kathmandu Valley, Kingdom of Nepal, Japan International Cooperation Agency (JICA) and Ministry of Home Affairs (MOHA), Tokyo.

Martin, S. S., Hough, S. E., and Hung, C., 2015. Ground motions from the 2015 M 7.8 Gorkha, Nepal, earthquake constrained by a detailed assessment of macroseismic data, Seismological Research Letters 86(6), 1524-1532.

McGowan, S. M., Jaiswal, K. S., and Wald, D. J., 2016. Using structural damage statistics to derive macroseismic intensity within the Kathmandu valley for the 2015 M7. 8 Gorkha, Nepal earthquake, Tectonophysics vol. 714-715, 158-172, https://doi.org/10.1016/j.tecto. 2016.08.002.

Moribayashi, S., and Maruo, Y., 1980. Basement topography of the Kathmandu Valley, NepalAn application of gravitational method to the survey of a tectonic basin in the Himalayas, Journal of the Japan. Society of Engineering Geology 21(2), 80-87.

Moss, R. E., Thompson, E. M., Kieffer, D. S., Tiwari, B., Hashash, Y. M., Acharya, I., Adhikari, B. R., Asimaki, D., Clahan, K. B., and Collins, B. D., 2015. Geotechnical effects of the 2015 magnitude 7.8 Gorkha, Nepal, earthquake and aftershocks, Seismological Research Letters 86(6), 1514-1523.

Mugnier, J-L., Huyghe, P., Gajurel, A. P., Upreti, B. N., and Jouanne, F., 2011. Seismites in the Kathmandu basin and seismic hazard in central Himalaya, Tectonophysics 509(1), $33-49$.

Nakata, T., Kumura, K., and Rockwell, T., 1998. First successful paleoseismic trench study on active faults in the Himalaya. Eos Transactions American Geophysical Union, 79, 45, Fall Meet Suppl., Abstract S22A-18.

Pandey, M. R., 2000. Ground response of Kathmandu Valley on the basis of microtremors, in $12^{\text {th }}$ World Conference on Earthquake Engineering (12 WCEE), 30 January-4 February 2000, Paper 2106.

Pandey, M. R., and Molnar, P., 1988. The distribution of intensity of the Bihar-Nepal earthquake of 15 January 1934 and bounds on the extent of the rupture zone, Journal of Nepal Geological Society 5(1), 22-44. 
Paudyal, Y. R., Bhandary, N. P., and Yatabe, R., 2012a. Seismic microzonation of densely populated area of Kathmandu Valley of Nepal using microtremor observations, Journal of Earthquake Engineering 16(8), 1208-1229.

Paudyal, Y. R., Yatabe, R., Bhandary, N. P., and Dahal, R. K., 2012b. A study of local amplification effect of soil layers on ground motion in the Kathmandu Valley using microtremor analysis, Earthquake Engineering and Enginering Vibration 11(2), 257-268.

Piya, B. K., 2004. Generation of a Geological Database for Liquefaction Hazard Assessment in Kathmandu Valley, Ph.D. Thesis, International Institute for Geoinformation Science and Earth Observation, Enschede, Netherlands.

Rajaure, S., Asimaki, D., Thompson, E. M., Hough, S., Martin, S., Ampuero, J. P., Dhital, M. R., Inbal, A., Takai, N., Shigefuji, M., Bijukchhen, S., Ichiyanagi, M., Sasatani, T., and Paudel, L., 2016. Characterizing the Kathmandu Valley sediment response through strong motion recordings of the 2015 Gorkha Earthquake sequence, Tectonophysics, http://dx.doi.org/10. 1016/j.tecto.2016.09.030

Rajaure, S., Sapkota, S. N., Adhikari, L. B., Koirala, B., Bhattarai, M., Tiwari, D. R., and Bollinger, L., 2013. Double difference relocation of local earthquakes in the Nepal Himalaya, Journal of Nepal Geological Society 40, 133-142.

Rana, B. J. B., 1935. Nepal Ko Maha Bhukampa (Great Earthquake of Nepal), Kathmandu Nepal, Jorganesh Press, Kathmandu, Nepal (in Nepali).

Sakai, T., Gajurel, A. P., Tabata, H., and Upreti, B. N., 2001. Small-amplitude lake-level fluctuations recorded in aggrading deltaic deposits of the Upper Pleistocene Thimi and Gokarna formations, Kathmandu Valley, Nepal, Journal of Nepal Geological Society 25, 43-52.

Sapkota, S. N., Bollinger, L., Klinger, Y., Tapponnier, P., Gaudemer, Y., and Tiwari, D., 2013. Primary surface ruptures of the great Himalayan earthquakes in 1934 and 1255, Nature Geoscience 6(1), 71-76.

Sharma, M. L., Douglas, J., Bungum, H., and Kotadia, J., 2009. Ground-motion prediction equations based on data from the Himalayan and Zagros regions, Journal of Earthquake Engineering 13(8), 1191-1210.

Sheehan, A. F., Torre, T., Monsalve, G., Schulte-Pelkum, V., Bilham, R., Blume, F., and Rajaure, S., 2008. Earthquakes and crustal structure of the Himalaya from the Himalayan Nepal Tibet Seismic Experiment (HIMNT), Journal of Nepal Geological Society 38, 1-8.

Stöcklin, J., 1980. Geology of Nepal and its regional frame Thirty-third William Smith Lecture, Journal of Geological Society 137(1), 1-34.

Szeliga, W., Hough, S., Martin, S., and Bilham, R., 2010. Intensity, magnitude, location, and attenuation in India for felt earthquakes since 1762, Bulletin of the Seismological Society of America 100(2), 570-584.

Vrettos, Ch., 1990. In-plane vibrations of soil deposits with variable shear modulus: II. Line load, International Journal for Numerical Analytical Methods in Geomechanics 14, 649-662. doi:10.1002/nag.1610140905

Yoshida, M., and Igarashi, Y., 1984. Neogene to Quaternary lacustrine sediments in the Kathmandu Valley, Nepal, Journal of Nepal Geological Society 4, 73-100.

(Received 31 January 2017; accepted 6 October 2017) 